\title{
A Study Of Path-Goal Relations Between Leaders Of College Principals And Their Subordinates In Pakistan
}

Riffat-un-Nisa Awan, University of Sargodha, Pakistan

Nayyar Raza Zaidi, Lahore School of Economics, Pakistan

\begin{abstract}
This study was designed to investigate the relationship among leadership behavior of degree college principals, selected organizational and personal characteristics, and faculty job satisfaction, acceptance of leader and job expectancies. The moderators included task structure, role ambiguity, stress, need for autonomy, need for achievement, perception about ability and locus of control. Responses were received from 854 college faculty members. Correlation analysis indicated that leadership styles were positively related to job expectancies and negatively related to acceptance of leader and job satisfaction. There were no differences between male and female respondents on any dependent measure. Majority was satisfied with their work on the job, supervision, coworkers and job in general and were dissatisfied with their pay and the promotion policy. Regression analysis indicated that only experience and length of service under current principal had significant affect on acceptance and satisfaction.
\end{abstract}

Keywords: Leadership Style, task structure, need for autonomy, need for achievement, perception about ability and locus of control, Job Satisfaction and Job Expectancies

\section{INTRODUCTION}

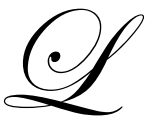

eadership is a universal phenomenon that has been defined and studied at great lengths from a vide variety of perspectives and disciplinary approaches (Yukl, 1981). As a result there are currently many definitions of the term "Leadership", as well as many different theories by which leadership issues can be explored. A leader is a person who has the ability to get others to do willingly what the leader desires to be done. A leader motivates others to action. Thus, it is the motivation of others and their actions that defines a successful leader.

Over the years, researchers and practitioners have developed a variety of views on leadership. Three major kinds of theories have been emerged from these on going studies. Trait theories deal with the personal characteristics of leader (Stogdill 1953), behavior theories deal with the behavior of leaders and contingency theories deal with the leadership in the context of specific situation (Fiedler, 1965; Heresy \& Blanchard, 1984; House, 1971).

The inability of the trait approach to consistently define specific traits that would differentiate successful and unsuccessful leaders led researchers to investigate other variables especially the behavior or actions of leaders. When trait and behavior approaches failed to be an adequate overall theory of leadership, researcher turned their attention to the situational aspects of leadership (Fiedler, 1965; Heresy \& Blanchard, 1984; House, 1971).

The goal of situational models is to identify important situational factors and to specify how they interact to determine appropriate leader behavior. These types of theories revolve around the concept that situational factors or intervening variables affect the relationship between leader behavior, subordinate job satisfaction, performance, and moral. Four of the most widely known contingency theories are the situational leadership Model, (Heresy \&Blanchard, 1982) The leadership contingency model, (Fiedler, 1965) the leadership decision-making model, 
(Vroom \& Yetton, 1973) and the Path-goal model (House, 1971). A more detailed discussion of situation theories is beyond the scope of this research. Because Path-goal model was used in this research so only this theory will be discussed briefly.

According to House (1996) "the essence of the theory is the meta proposition that leaders to be effective, engage in behaviors that complement subordinates' environments and abilities in a manner that compensates for deficiencies and is instrumental to subordinate satisfaction and individual and work unit performance." (p. 323) Path-goal theory has four general propositions based on the works of House (1971), House and Dessler (1974), and House and Mitchell (1974). These propositions form the foundation of path-goal theory and include:

1. Subordinates will accept a superior's behavior if it is an immediate source of satisfaction or instrumental to future satisfaction (House and Mitchell, 1974).

2. A superior's behavior may increase effort when it makes satisfaction of a subordinate's needs contingent upon effective performance and/or when it complements the work environment through coaching, guidance, support, and rewards necessary for effective performance (House \& Mitchell, 1974).

3. One of a superior's strategic functions is to enhance a subordinate's psychological state in such a way that it would result in an increase in motivation to perform and job satisfaction (House \& Mitchell, 1974).

4. The particular leader behavior that will enhance motivation is determined by the situation (House \& Dessler, 1974).

Path-goal theory is a vehicle for identifying how a subordinate's needs, values, and expectations interact with the individual's job in order to determine the degree of job satisfaction. It can be used to suggest what type of leadership behavior may be most effective under specific situations. It may also be used to explain why a particular type of leadership is most effective under a given set of conditions. The reinforcement of change in the subordinate by the leader is a prominent aspect of path-goal theory.

Like Fiedler's contingency theory of leadership, the path-goal theory does not specify one best way to lead. Rather, it stresses that to be effective; a leader should select the style most appropriate to a particular situation. Pathgoal theory holds that, depending on subordinate characteristics, each of the four types of leader behavior will be used by an effective leader in different situations. Under this theory, the style a leader uses depends on the situation, so leaders must be flexible and adopt the style that is required.

\section{VARIABLES OF PATH-GOAL THEORY}

Path-goal theory is used to examine the effects of four leader behaviors on three subordinate outcomes. In the path-goal theory there are two categories of situational variables which have been identified as having an impact on leader behavior and subordinate outcomes. These four leader behaviors, eight situational factors and three outcomes are shown in Figure 1.

The present study is correlational study designed to find out the relationship between path-goal variables. The current study involves Locus of Control, Perception about Abilities and Need for Autonomy from the subordinate characteristics and from organizational characteristics only Task Structure was the part of this study and stress was included as an additional variable. Moreover all four leadership styles and all three subordinate outcomes were the part of this study.

The study aimed at answering the following research questions.

1. What is the relationship between leadership behavior and subordinate's acceptance of leader, expectancy I (effort leads to high performance), expectancy II (performance leads to reward) and job satisfaction of subordinates?

2. What is the relationship between attributes of subordinates (age, sex, qualification, faculty rank, experience and length of service under the current supervisor.) and subordinate's acceptance of leader, job expectancies and job satisfaction? 
3. What is the relationship between situational factors (task structure, role ambiguity, stress, need for autonomy, locus of control, need for achievement, \& perception about abilities) and subordinate's acceptance of leader, job expectancies and job satisfaction?

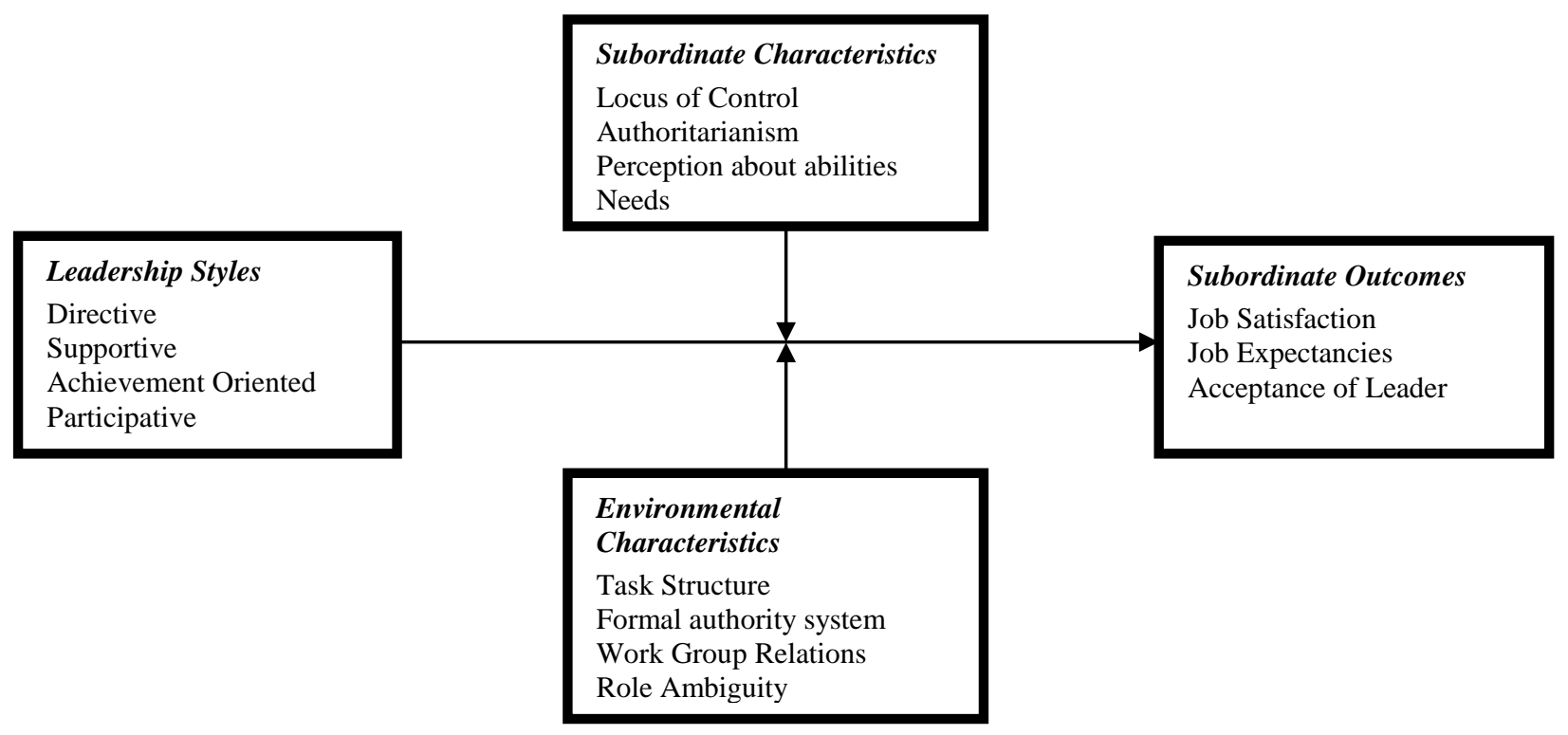

Figure 1. House, \& Mitchell. (1974)

\section{METHODS}

The population of the study consisted of teaching staff of all male and female degree colleges from the province of Punjab. Total number of degree colleges in Punjab was 285 (Male 144, Female 141) and number of working staff was 13821 (Male 8195, Female 5626), according to the statistics of Directorate of Public Instruction (Colleges) Punjab, from where complete lists of Degree Colleges of Punjab were collected. Geographical area for the population consisted of 34 districts of Punjab.Sample size of the study comprised of 170 Government Degree colleges and 1020 teachers (lecturers, Assistant professors, Associate professors, professors) teaching in these colleges.

Sample selection. All thirty-four districts of Punjab were included in the sample. Six degree colleges (3 male, 3 female) from each district were selected randomly. From each college 6 teachers were selected randomly. Total number of degree colleges was 285 . It was observed that there were 87 colleges (31\%) in only 4 districts of Punjab, while in remaining 30 districts the average number of colleges was only six. So it was decided to take six colleges from each district to make the sample more representative. The remote districts where the number of colleges was less than six, all colleges were included in the sample to give them more representation. Resultantly the total sample size was 170 degree colleges.

Instrument. There was a combination of four sets of questions that measured the four leader behaviors developed and factor analyzed by House and Dessler (1974). Task structure for this study was measured using a 10-item scale constructed by House and Dessler (1974). The scale was found to have Kuder-Richardson Formula 20 reliability of .69 for the two samples used in the study. The Job Expectancies scales developed by House and Dessler (1974) were used for this study to measure Job Expectancy I and Expectancy II. Both of these scales were found to have adequate reliability. Kuder-Richardson scores were in the range of .84 to .88 . The questions used to measure subordinates' Role Ambiguity in this study were from Rizzo, House, and Lirtzman's (1970) research entitled "Role Conflict and Ambiguity in Complex organizations". The Job Descriptive Index (JDI) and the Job in General Scale (JDI) (Blazer 
et al, 2000) were utilized in this study to measure Job Satisfaction. All four types of satisfaction including intrinsic, extrinsic, superior and over-all satisfaction can be tested. The JDI yields five sub-scale scores including Work, Pay, Opportunities for Promotion, Supervision, and Coworkers, as well as an over-all Job Satisfaction score. The authors of the JDI reported split half-internal consistency reliability of the five JDI scales ranging from .80 to .88 , across six samples.

All these scales were adopted and used for the purpose of data collection. All these instruments had been developed specifically to test the path-goal theory and had been used by many researchers ((Downey, Sheridan, and Slocum, 1975; Greene, 1974; Schriesheim, \&. Glinow, 1977; Szilagyi, and Sims, 1974; Stinson and Johnson, 1975)

Romeo, 1992; Szilagyi \& Sims, 1975) and found reliable.

For subordinate characteristics the researcher herself constructed questionnaires entitled "Subordinate Personal Characteristics Scale", after extensive study of related literature and wide ranging consultation with the educational experts. (Bass, 1990; Downey, Sheridan, and Slocum, 1975; Greene, 1974; House \& Terence, 1974; Schriesheim, \&. Glinow, 1977; Sims, and Szilagyi, 1975, Stinson and Johnson, 1975; Romeo, 1992; Sergiovanni,1991; Szilagyi \& Sims, 1974, 1975; Yukl, 1981). Demographic Variables Information Performa consisted of six items seeking information about college teachers attributes such as age, sex, qualification, faculty rank, teaching experience and length of service under current principal, was also used.

After the initial construction of the research tool, a pilot study was conducted using a total of 39 college teachers as the sample. So far as reliability and validity of measuring instrument was concerned, following instruments in their original had high reliability and validity but in a different context. As their modified versions were prepared, this warranted establishment of their reliability and validity afresh. The results of this exercise using Cronback coefficient alpha were summarized in the table.

Table. 1

\begin{tabular}{llc}
\hline & Questionnaire & Reliability \\
1 & Leader behavior items & 0.91 \\
2 & Task Structure scale & 0.75 \\
3 & Job Expectancy scale & 0.83 \\
4 & Role Ambiguity scales & 0.72 \\
5 & Anxiety and Stress scale & 0.74 \\
6 & Job Descriptive Index & 0.91 \\
7 & Acceptance of leader & 0.84 \\
8 & Subordinates' Characteristics Scale & \\
& Perception about ability & 0.86 \\
& Need for Autonomy & 0.87 \\
& Locus of Control & 0.70 \\
& Need for Achievement & 0.90 \\
\hline
\end{tabular}

The statistical analysis was conducted with the help of computer using Statistical Package for Social Science (SPSS). Pearson-Product Moment Correlation Coefficient, and Regression Analysis techniques were used to find out the relationship among the path-goal variables.

\section{FINDINGS}

These findings are based on the data taken from fifty five $\%$ male and $45.4 \%$ female lecturers of degree colleges. Majority of the respondents were below the age of 45 , which comprised 78.8 percent. The respondents of higher age group were only 4.3 percent. Only 1.9 percent of the total lecturers had a doctorate degree, 10.4 percent had earned M Phil degree and a bulk i.e. $87.7 \%$ had master's degree. Five hundred and fifty four respondents were lecturers, which comprised 64.9 percent of total sample. Only 13 respondents were full professors while assistant professors and associate professors were 25.2 percent and 8.4 percent respectively. Majority of the respondents i.e. 
$31 \%$ had less than five years experience. About 29 percent had 6-10 years experience and 30 percent had 11-20 years experience while highly experienced group was in low percentage. The main findings of the study are as unders:

1. There was significant negative relationship between four leadership behaviors and subordinate acceptance of leader but it was significantly positive between leadership behaviors and subordinate job expectancies. This relationship was again significantly negative between leader behaviors and six facets of subordinate job satisfaction. These findings are clear in the following table.

Table 1: Pearson $r$, of Leadership Behavior and Subordinate Outcomes

\begin{tabular}{|c|c|c|c|c|c|c|c|c|c|c|}
\hline & $\stackrel{\varrho}{\Xi}$ & $\frac{8}{8}$ & i্⿳亠丷⿵冂丶 & 䒽 & 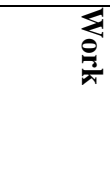 & $\bar{\psi}$ & & Sִ & 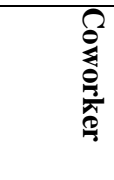 & 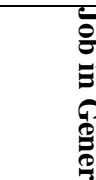 \\
\hline Directive & 854 & -.525 & .327 & .355 & -.191 & -.096 & -.097 & -.281 & -.114 & -.141 \\
\hline Supportive & 854 & -.690 & .309 & .355 & -.120 & -.159 & -.148 & -.336 & -.174 & -.162 \\
\hline Participative & 854 & -.655 & .297 & .366 & -.120 & -.140 & -.147 & -.321 & -.137 & -.173 \\
\hline Ach-Ori & 854 & -.600 & .337 & .445 & -.123 & -.122 & -.167 & -.335 & -.135 & -.146 \\
\hline
\end{tabular}

2. Regression analysis for attributes of subordinates (age, sex, qualification, faculty rank, experience and length of service under the current supervisor.) as predictor of acceptance of leader. The $F$ value $(6,853)$ 2.840 was greater than critical value 2.10 at .05 level of significance. The $t$-values of predictor variables were non-significant except the experience and length of service, so it was concluded that experience and length of service under the current supervisor, can be used as predictor of acceptance of leader.

Table 2: Multiple Regression Analysis; Age, Sex, Qualification, Designation, Experience, and Length of Service under

\begin{tabular}{llllllll}
\multicolumn{7}{c}{ Current Principal and Acceptance of Leader } \\
Predictors & B & $\boldsymbol{t}$-value & $\boldsymbol{p}$ & $\boldsymbol{R}$ & $\boldsymbol{F}$-Ratio & Sig. & R-Square \\
\hline Age & -.061 & -1.260 & .208 & .296 & & .362 & .17 \\
Sex & .067 & 1.904 & .057 & .364 & 2.840 & .022 & \\
Qualification & -.034 & -.972 & .331 & .455 & & \\
Designation & -.010 & -.244 & .808 & .298 & & \\
Experience & .128 & 2.816 & .005 & .218 & & \\
Service & -.074 & -2.095 & .036 & .290 & & \\
\hline
\end{tabular}

3. The Multiple Regression equation for attributes of subordinates (age, sex, qualification, faculty rank, experience and length of service under the current supervisor) as predictor variables of expectancy I (table 3) made it clear that individual variables, gender, experience and length of service under the current supervisor, made a significant contribution and can be used as predictor of expectancy I.

Table 3: Multiple Regression Analysis; Age, Sex, Qualification, Designation, Experience, and Length of Service under Current Principal and Expectancy I

\begin{tabular}{llllllll}
\hline Predictors & $\boldsymbol{t}$-value & $\mathbf{B}$ & $\boldsymbol{p}$ & SE(est.) & $\boldsymbol{F}$-Ratio & Sig. & R-Square \\
\hline Age & -.174 & -.008 & .862 & .167 & & & \\
Gender & -2.033 & -.071 & .042 & .205 & 3.344 & .033 & .023 \\
Qualification & 1.367 & .048 & .172 & .256 & & \\
Designation & .426 & .017 & .671 & .168 & & \\
Experience & -2.177 & -.098 & .030 & .123 & & \\
Service & 3.270 & .115 & .001 & .164 & & \\
\hline
\end{tabular}


4. Regression analysis for attributes of subordinates (age, sex, qualification, faculty rank, experience and length of service under the current supervisor.) as predictor of expectancy II was not significance, which means that attributes of subordinates can not be used as predictors of expectancy II. This equation was also non-significant for attributes of subordinates and job satisfaction.

5. Table 4 gives the values of the regression equation for (task structure, role ambiguity, stress, need for autonomy, locus of control, need for achievement, \& perception about abilities) and subordinates' acceptance of leader was significant, so it was concluded that individual variables, task structure, role ambiguity, stress, and need for achievement, made a significant contribution and can be used as predictor of acceptance of leader. Three variables need for autonomy, locus of control and perception about ability were not significant. Apart from task structure all other variables had negative contribution to acceptance of leader. It means that as role ambiguity, stress and need for achievement increases acceptance of leader decreases.

Table 4: Multiple Regression Analysis; Task Structure, Role ambiguity, Stress, Need for Autonomy, Locus of Control, Need for Achievement, Perception about Abilities and Acceptance of Leader

\begin{tabular}{lllllll}
\hline Predictors & $\mathbf{B}$ & $\boldsymbol{t}$-value & $\boldsymbol{P}$ & $\boldsymbol{S E}(\boldsymbol{e s t}$. $)$ & $\boldsymbol{F}$-Ratio & $\boldsymbol{R}^{2}$ \\
\hline Task Structure & .099 & 3.741 & .000 & .027 & 89.078 & .425 \\
Role ambiguity & -.152 & -5.158 & .000 & .037 & $.7,843)$ & \\
Stress & -.157 & -5.866 & .000 & .031 & .039 & \\
Autonomy Need & -.003 & -.128 & .899 & .033 & \\
Locus of control & -.028 & -1.023 & .307 & .053 & \\
Achievement Need & -.498 & -17.071 & .000 & .051 & \\
Ability & .002 & .063 & .950 & & \\
\hline
\end{tabular}

6. The regression equation for situational factors (Task Structure, role ambiguity, stress, need for autonomy, locus of control, need for achievement, \& perception about abilities) as predictors of subordinates' job expectancy I was significant. Keeping in view the $t$ values it was concluded that all situational factors other than task structure and locus of control could be used as predictor of job expectancy I.

Table 5: Multiple Regression analysis: Task Structure, Role ambiguity, Stress, Need for Autonomy, Locus of Control,

\begin{tabular}{lllllll}
\multicolumn{7}{c}{ Need for Achievement, Perception about Abilities and Job Expectancy I } \\
\hline Predictors & B & $\boldsymbol{t}$-value & $\boldsymbol{P}$ & SE(est.) & $\boldsymbol{F}$-Ratio & $\boldsymbol{R}^{2}$ \\
\hline Task Structure & -.034 & -1.330 & .184 & .014 & & \\
Role ambiguity & .611 & 21.442 & .000 & .020 & 104.89 & .466 \\
Stress & .063 & 2.445 & .015 & .017 & $(7,843)$ & \\
Autonomy Need & .074 & 2.867 & .004 & .021 & \\
Locus of control & .031 & 1.190 & .234 & .018 & \\
Ach-Need & .062 & 2.204 & .028 & .029 & .028 & \\
Ability & -.065 & -2.476 & .013 & .028 & \\
\hline
\end{tabular}

7. According to Regression Analysis for situational factors (Task Structure, role ambiguity, stress, need for autonomy, locus of control, need for achievement, \& perception about abilities) as predictors of subordinates' job expectancy II, the analysis of the data resulted in very strong R-Square of .46 which implies that the situational factors accounted for 46 percent of the variation in expectancy II. It was concluded that individual variables made significant contributions, role ambiguity, $t(853)=-19.063, p=$ .000 , need for achievement, $t(853)=7.216, p=$. 000, perception about abilities, $t(853)=-2.325, p=$ .021 and can be used as predictor of expectancy II. The two variables role ambiguity and perception about abilities were negatively related to expectancy II, it means that as the role ambiguity and perception about abilities increases, job expectancy II decreases. 
Table 6: Multiple Regression analysis: Task Structure, Role ambiguity, Stress, Need for Autonomy, Locus of Control,

\begin{tabular}{|c|c|c|c|c|c|c|}
\hline \multicolumn{7}{|c|}{ Need for Achievement, \& Perception about Abilities and Job Expectancy II } \\
\hline Predictors & B & $t$-value & $p$ & SE(est.) & $F$-Ratio & $R^{2}$ \\
\hline Task Structure & .008 & .307 & .759 & .016 & & \\
\hline Role ambiguity & .548 & 19.063 & .000 & .022 & 100.754 & .456 \\
\hline Stress & .010 & .370 & .712 & .019 & $(7,853)$ & \\
\hline Autonomy Need & -.030 & -1.160 & .246 & .024 & & \\
\hline Locus of control & .022 & .833 & .405 & .020 & & \\
\hline Achievement Need & .205 & 7.216 & .000 & .032 & & \\
\hline Ability & -.062 & -2.325 & .020 & .031 & & \\
\hline
\end{tabular}

8. The analysis of the data resulted in R-Square of .189 for situational factors and job satisfaction. The regression equation for situational factors and job satisfaction was significant, $F(7,840) 27.906, p=.000$. It was concluded that task structure, stress, and need for achievement, could be used as predictor of job satisfaction while stress and need for achievement had negative contribution to job satisfaction

Table 7: Multiple Regression analysis: Task Structure, Role Ambiguity, Stress, Need for Autonomy, Locus of Control, Need for Achievement, \& Perception about Abilities and Subordinates' Job Satisfaction

\begin{tabular}{lllllll}
\hline Predictors & $\boldsymbol{\beta}$ & $\boldsymbol{t}$-value & $\boldsymbol{p}$ & $\boldsymbol{S E}(\boldsymbol{e s t}$. $)$ & $\boldsymbol{F}$-Ratio & $\boldsymbol{R}^{2}$ \\
\hline Task structure & .085 & 2.704 & .007 & .163 & & .189 \\
Role ambiguity & -.049 & -1.389 & .165 & .225 & 27.906 & .189 \\
Stress & -.280 & -8.779 & .000 & .187 & $(7,840)$ & \\
Autonomy Need & .009 & .276 & .783 & .238 & & .202 \\
Locus of control & -.007 & -.206 & .837 & .328 & & \\
Achievement Need & -.229 & -6.585 & .000 & .313 & \\
Ability & .021 & .650 & .516 & .313 \\
\hline
\end{tabular}

\section{DISCUSSION AND CONCLUSION}

On the bases of findings of the study, following conclusions were drawn:

The independent variable, leadership styles (directive, supportive, participative and achievement-oriented) had significant effect on dependent variables of acceptance of leader, job expectancies and six facets of job satisfaction. All four leadership styles were negatively related to acceptance of leader and job satisfaction but positively related to job expectancies.

There were no differences between male and female respondents on any dependent measure. The demographic variables had no affect on job expectancy II and job satisfaction. Only experience and length of service had significant effect on job expectancy I and acceptance of leader. The new variable stress, which was included as an additional variable, had negative significant correlation with acceptance of leader and job satisfaction. It means that this variable had the potential to be included as a moderating variable in path-goal theory.

On 'Job Descriptive Index' the majority of the responses were negative with regard to the pay and promotion. It means that people were more dissatisfied with their pay and the promotion policy. Majority of the respondents was satisfied with their work on the job, supervision, coworker and job in general.

Moreover the results reveal that majority of the respondents perceive their principal as low on each dimension. This is because the interaction between principals and their teaching staff is very low in the degree colleges of Punjab. Teachers come to the college, take their classes and go back to their homes. They have little to do with their principals. Oftentimes they even don't meet with their principals. On the other side principals often remain in their offices and don't take the round of the college and even don't monitor if the lecturers are delivering their lectures regularly. Whereas in business organizations which are profit-oriented organizations, leaders can not be successful with such laizzes-faire attitude. Path-goal theory which is basically designed for business organizations, 
has been tested mostly with the population from business sector and the difference of above mentioned results is only due to the difference of the population and the peculiar nature and the culture of these institutes. The negative relationship of leadership behavior with acceptance of leader and job satisfaction means that more the principals were high directive or high participative etc. the less the acceptance and satisfaction was. This means that teachers of degree colleges don't want any interference of their principals with regard to their job assignment i. e. teaching, and wanted to work independently. So far as relationship of leadership behavior and job expectancies is concerned, it was positive in direction. It means that people put more effort in their work when their principals were strong in their leadership behavior whether it was supportive or achievement-oriented. Job expectancy II had positive relationship with leadership styles, which (Job expectancy II) means that people improve their performance because they believe that high performance will lead to more rewards. When we see the reward system of our degree colleges we come to the conclusion that principals have a little role in enhancing or reducing the rewards of their employees as they are not authorized to increase the pay as a reward or decrease it as a penalty and punishment. They can't hire or fire their employees, and even have no role in transfer policy of their subordinates. So to this point this relationship becomes irrelevant. But this doesn't mean that they had no reward with them, even a pat on the back, an encouraging smile, a best worded praise, any prestigious designation (chairman of any committee), and praise before colleagues had a great effect and can work effectively to improve motivation. Most of the respondents considered their principals as achievement-oriented leaders. This was possibly because of the particular nature of the population as this study was conducted in degree colleges of the Punjab and principles are responsible only to assign the roles and responsibilities. They bother less about the quality of the work and standard of education as compared to secondary schools and universities so subordinates are rating them as achievement oriented.

The demographic variables had no affect on job expectancy II and job satisfaction. Only experience and length of service under current principals had significant effect on job expectancy I and acceptance of leader, but the relationship of experience was positive with acceptance of leader and length of service was negatively related with acceptance of leader and the case was reverse for job expectancy I. There is no possible explanation of this contradiction, because both the variables are interrelated as more length of service means more experience. There is only one point which can be helpful to understand this problem that is, the length of service was measured only upto ten years whereas experience was measured upto thirty years. But this assumption can not be confirmed from the data and the results of this research.

The new variable stress, which was included as an additional variable, had negative significant correlation with acceptance of leader and job satisfaction. It means that this variable had the potential to be included as a moderating variable in path-goal theory. The second important finding related to stress was only 51 respondents out of 854 rate themselves as highly stressed, 73 respondents were experiencing moderate stress, while 728 respondents rate themselves as experiencing low stress or no stress. It means that majority of the respondents were not under high stress. This was because lecturers enjoy a very comfortable job as the workload is always very low and astonishingly it was also found out by the researcher that they work only 170 days a year on the average.

The results of Job Satisfaction gave a very different picture. On Job Descriptive Index the majority of the respondents were satisfied with their job but not with their pay and the promotion policy, measured on Job Descriptive Index. It means that people were satisfied with their work on the job, supervision, coworker and job in general but they were not satisfied with their pay and the promotion policy. The dissatisfaction with the pay is understandable keeping in view the rising prices of commodities and livelihood. The second facet of job satisfaction where respondents showed dissatisfaction was promotion policy. In Punjab the promotion policy is based on seniority of the employees. The dissatisfaction of respondents with promotion policy can be traced in the demographics of the respondents as majority of them were lecturers (64.9\%) and between age of 25-35 (40\%). They don't have fair chances of promotion in the near future. $88.4 \%$ of the total population was satisfied with their job in general (JIG). This was because the job of lecturers in Pakistan is very prestigious with very little workload.

All these results clearly indicate that principals of degree colleges needs to understand and take into account the dynamics of the groups, nature of the work assignments and personal characteristics of the teaching faculty to be successful in their organizations and to perform an effective leadership role. Leadership can not be performed in vacuum. Leaders need to understand the situational factors that are working behind the seen. 


\section{AUTHOR INFORMATION}

Dr. Riffat-un-Nisa Awan M.Ed., PhD is an Assistant Professor, Department of Education, University of Sargodha, Pakistan. Her Area of Expertise/interest: Attitude studies in science and Educational leadership and administration.

\section{REFERENCES}

1. $\quad$ Bass, B.M. (1990). Bass and Stogdill's handbook of leadership. New York: Macmillan.

2. $\quad$ Blazer, W. J., Kihm, J.A., Smith, P.C., Irwin, J.L., Bachiochi, P.D., Robie, C., Sinar, E. F., \& Parra, L. F. (2002). Users' Manual for the Job Descriptive Index (JDI; 1997 version) and the Job in General Scales. In J. M. Stanton, and C. D. Crossley, (Eds), Electronic resources for the JDI and JIG. Bowling Green, OH: Bowling Green State University

3. Dessler, G. (1973). An investigation of a path-goal theory of leadership. Dissertation Abstract International, City University Of New York. VOL. 34-02A.

4. Downey, H. K., J. E. Sheridan, and J. W. Slocum. (1975). Analysis of Relationships Among Leader Behavior, Subordinate Job Performance and Satisfaction: A Path-Goal Approach. Academy of Management Journal, Vol. 18 , 253-262.

5. Evans, M.G. (1970). The effects of supervisory behavior on the path-goal relationship. Organizational Behavior and Human Performance, 5,277-298.

6. $\quad$ Fiedler, F.E. (1965). A theory of leadership effectiveness. NY: McGraw Hill.

7. Green, S.B., Salkind, N.J. and Akey, T.M. (1997). Using SPSS for windows. NJ: Prentice Hall.

8. Greene, C. N. (1974). The Path-Goal Theory of Leadership: A Replication and an Analysis of Causality. Academy' of Management Proceedings, 1974, p. 47.

9. Hersey, P., and Blanchard, K. H (1984). Management of organizational behavior (4th ed.) NJ: Prentice Hall

10. House R. J. (1971). A path goal theory of leader effectiveness, Administrative Science Quarterly, 16, 3, 321-338.

11. House, R. J. \& Baetz, M.L. (1979). Leadership: Some empirical generalizations and new research directions. Research in Organizational Behavior, 1,341-423.

12. House, R. J. \& Dessler, G. (1974). Path goal theory of leadership: Some post hoc and a priori tests. In Contingency approaches to leadership, JG Hunt and L.L. Larson (Eds.), Carbondale, IL: Southern Illinois University.

13. House, R. J. \& Mitchell,T.R. (1974). Path goal theory of leadership in Fred Luthans (ed.) Contemporary Readings in Organizational Behavior. New York: McGraw Hill.

14. House, R. J., (1996). Path-goal theory of leadership: Lessons, legacy, and a reformulated theory, Leadership Quarterly, 7-3, 323-325.

15. Huse, E.F. \& Bowditch, J.L. (1977). Behavior in organizations. Massachusetts: Addison Wesley.

16. Indvik, J. (1985). A path-goal theory: Investigation of superior-subordinate relationships (Leadership, Downward communication, Supervision). The University of Wisconsin-Madison. Dissertation Abstract International, Vol. 46-12A.

17. Rizzo, J. R., R. J. House, and S. E. Lirtzman, (1970). Role Conflict and Ambiguity in Complex Organizations. Administrative Science Quarterly, Vol. 15 (1970), 150-163.

18. Romeo, C. C. (1992). A test of path- goal theory: the effects of leadership and faculty satisfaction in pubic baccalaureate nursing programs. ( doctoral dissertation, University of Maryland College Park). Dissertation Abstract International.

19. Schriesheim, C. and M. A. Glinow, (1977). The Path-Goal Theory of Leadership: A Theoretical and Empirical Analysis. The Academy of Management Journal, Vol. 20, No. 3, pp. 398-405

20. Sergiovanni, T.J. (1991). The principalship: A reflective practice perspective. Boston: Allyn \& Bacon.

21. Sims, H. P., and A. D. Szilagyi. (1975). Leader Structure and Subordinate Satisfaction for Two Hospital Administrative Levels: A Path Approach. Journal of Applied Psychology, Vol. 60, 194-197. 17.

22. Stinson, J. E., and T. W. Johnson. (1975). The Path-Goal Theory of Leadership: A Partial Test and Suggested Refinement," Academy of Management Journal, Vol. 18 (1975), 242-252.

23. Stogdill, R.M. (1953). Aspect of leadership and organization. Ohio: The Ohio State University 
24. Szilagyi, A. D., and H. P. Sims. (1975). Leader structure and subordinate satisfaction for two hospital administrative levels: A path analysis approach. Journal of Applied Psychology. Vol. 2 pp. 194-197

25. Szilagyi, A. D., and H. P. Sims. (1974). An Exploration of the Path-Goal Theory of Leadership in a Health Care Environment. Academy of Management Journal, Vol. 17, 622-634.

26. Vroom,V.H. and.Yetton, P.W. (1973). Leadership and decision-making Pittsburgh: University of Pittsburgh.

27. Yukl, G.A. (1981). Leadership in organizations. $2^{\text {nd }}$ ed. Englewood Cliffs, NJ: PRENTICE-HALL, INC

\section{NOTES}

